\title{
Do Financial Sector Reforms Improve Competition of Banks? An Application of Panzar and Rosse Model: The Case of Ghanaian Banks
}

\author{
George Owusu-Antwi ${ }^{1} \&$ James Antwi ${ }^{2}$ \\ ${ }^{1}$ Finance, Business School, Ghana Institute of Management and Public Administration, Accra, Ghana \\ ${ }^{2}$ Project Management, School of Technology, Ghana Institute of Management and Public Administration, Accra, \\ Ghana \\ Correspondence: George Owusu-Antwi, Visiting Lecturer, Finance, Business School, Ghana Institute of Management \\ and Public Administration, P. O. Box AH 50, Achimota, Accra, Ghana. Tel: 233-24-344-6649. E-mail: \\ georgegowu@yahoo.com
}

Received: January 30, 2013

Accepted: April 2, 2013

Online Published: June 24, 2013

doi:10.5430/ijfr.v4n3p43

URL: http://dx.doi.org/10.5430/ijfr.v4n3p43

\begin{abstract}
The study investigated the market structure of Ghana's banking industry and determined whether the market structure has been changed after the financial restructuring. This study specifically measures the degree of competition of the banking system in Ghana by using the H-statistics. Various studies on the degree of competition were reviewed. This study employs a widely used nonstructural methodology put forward by Panzar and Ross (1987) - the H-statistic - and drawn upon a comprehensive average annual data from the various issues of the Bank of Ghana annual reports from 1988 to 2011. Based on the reported H-statistic, it can be concluded that Ghana's banks are operating under perfect condition. However, the test for a change in competition status at the time of liberalization was not significant, indicating no evidence of a change in competition as a result of liberalization. This study has extended and strengthened some earlier results on bank competition in Ghana. However, the results of this study are different from the study undertaken by Buchs and Mathisen (2005), who found Ghanaian banking markets to operate under monopolistic conditions.
\end{abstract}

Keywords: banking, competition, financial restructuring, liberalization, financial market, market equilibrium, $\mathrm{H}$-statistic, financial sector adjustment program

\section{Introduction}

Since the early 1980s, there has been a major financial liberalization and institutional reforms program, a severe and a protracted economic crisis, and the pre-reform policies of the government of Ghana over financial markets had damaged the financial system, resulting to financial volatility and bank distress (Aryeetey\&Kanbur, 2005).

As a result, the last decade provides important lessons with regard to factors influencing the relationship between competition and concentration that have hitherto not been explored. In the early 1990s, the government launched a financial market liberalization policy under the Financial Sector Adjustment Program (FINSAP), supported by the International Monetary Fund and the World Bank. The objective was to restructure the distressed banks and clean up nonperforming assets in order to restore the banks to profitability and viability (Aryeetey\&Senbet, 2004). The FINSAP program set prices right, initiated structural reforms in the banking sector, including fiscal and monetary operations, as well as privatization. The removal of the restrictions on foreign and domestic market entries, and the privatization of state-owned banks increased the number of commercial banks doing business in their extremely concentrated and inefficient national markets and altered the competitive conditions.

The main motive behind privatization of state-owned banks was the desire to enhance competition and efficiency in the banking sector through increased foreign and domestic participation. Although concentration has increased, its explicit impact on competition in the banking sector remains an important policy question. Studies that have attempted to examine the effects of privatization on bank performance include that of Beck, Cull, and Jerome (2005). The result of their study showed that privatized banks performed worse than privately owned banks before privatization, but subsequently improved significantly after privatization. Otchere (2005) analyzed the pre- and post-privatization operating performance of privatized banks and nonprivatized banks in middle- and low-income countries and found 
marginal improvements in the post-privatization operating performance of the privatized banks. Bonin, Hasan, and Wachtel (2005b) also investigated the impact of privatization on bank performance and found financial performance to be improved significantly after divestiture. They explained that the cost of upgrading technology and developing new business lines has always been incurred by foreign owners. In Ghana, the Bank of Ghana (BOG, The Central Bank) rationalized the minimum reserve requirements for banks, introduced new financial instruments, and opened markets operations for liquidity management. These policies were complemented by improving the soundness of the banking system, regulatory framework, bank supervision, as well as improving the efficiency and profitability of banks, including the replacement of their nonperforming assets (Aryeetey\&Senbet, 2004; Buchs\&Mathisen, 2005).

The first stage of financial restructuring in Ghana had produced a substantial increase in the establishment of banks due to the relaxation of the banking regulations that allowed new banks to enter the banking industry without disabling restrictions. This has brought the number of banks to 25 at the end of 2011. Table 1 presents the number of banks in the Ghana banking industry.

Table 1. The Number of institutions and branches in the financial sector, as of December 2005

\begin{tabular}{|c|c|c|}
\hline & $\begin{array}{l}\text { Number } \\
\text { institutions }\end{array}$ & $\begin{array}{l}\text { Number } \\
\text { branches }\end{array}$ \\
\hline Commercial banks & 7 & 223 \\
\hline Large commercial banks & 3 & 193 \\
\hline Ghana commercial banks (GCB) & 1 & 135 \\
\hline Foreign-owned banks & 2 & 58 \\
\hline Small commercial banks & 4 & 30 \\
\hline Development banks & 3 & 78 \\
\hline Merchant banks & 2 & 6 \\
\hline Universal banks & 6 & 67 \\
\hline Subtotal & 18 & 374 \\
\hline Rural banks & 121 & 353 \\
\hline \multicolumn{3}{|l|}{ Insurance companies } \\
\hline Insurance companies & 23 & 48 \\
\hline Social Security and National Insurance Trust & 1 & 48 \\
\hline Other insurance companies & 22 & 0 \\
\hline Reinsurance companies & 2 & 0 \\
\hline Subtotal & 25 & 48 \\
\hline \multicolumn{3}{|l|}{ Other nonblank financial institutions } \\
\hline Building societies & 2 & \\
\hline Discount houses & 2 & - \\
\hline Finance companies & 14 & - \\
\hline Leasing companies & 5 & - \\
\hline Mortgage finance & 1 & 5 \\
\hline Savings and loans & 12 & - \\
\hline Venture capital funds & - & - \\
\hline Credit unions & 273 & - \\
\hline Subtotal & 309 & 14 \\
\hline Total financial sector & 473 & 789 \\
\hline
\end{tabular}

Note: From Annual Reports (p. 25), by Bank of Ghana, 2005. Accra, Ghana: Author.

The increase in the number of banks has caused the banking industry to be concentrated. The bank concentration ratio (CR) and Herfindahl-Herschman Index (HHI), which mostly measures bank concentration, suggests a concentration of Ghana's banking industry after the financial restructuring.

The purpose of this study is to investigate the market structure of Ghana's banking industry and determine whether the market structure has been changed after the financial restructuring. This study specifically measures the degree of competition of the banking system in Ghana by using the H-statistics developed by Panzar and Rosse. The paper incorporated all banks over the sample period of 26 years, from 1985-2011. This provides enough identification power to investigate the degree of competition in Ghana during and after the liberalization policy.

This study contributes to the literature both by extending the analysis of the relationship between bank competition and the financial restructuring in Ghana. Despite a growing body of literature on banking competition, a few studies have 
investigated the explanatory factors behind the competitiveness indicator. This is the first paper to use the Panzar and Rosse (PR) model to measure the impact of financial restructuring on the degree of competition in Ghana's banking system. The results of the study indicate that Ghanaians banks are operating under perfect condition. However, the test for a change in competition status at the time of liberalization was not significant, indicating no evidence of a change in competition as a result of liberalization. The result of the market equilibrium reveals that the market equilibrium equals to zero, revealing the existence of long-run equilibrium making the Panzar and Rosse model meaningful to interpret.

The remainder of the study is divided into five sections. The second section includes the literature that reviews the various studies on the degree of competition. Attention is focused on the empirical studies of bank competition. The third section identifies the data source and develops the model to assess the competitive structure of Ghana's banking system. The fourth section presents empirical results and interpretations. The final section is devoted to the conclusion.

\section{Literature Review on Competition}

Industrial organization theory has revealed that the competitiveness of an industry cannot be measured by market structure indicators alone, such as the number of institutions, or Herfindahl, and other concentration indexes (Baumol, Panzar, \&Willig, 1982). Economic theory, suggests that performance measures, such as the size of banking margins, interest spreads, or profitability, do not necessarily indicate the competitiveness of a banking system. These measures are manipulated by factors such as a country's macroeconomic performance and stability, the form of degree of taxation of financial intermediation, the quality of the country's information and judicial systems, and risk preferences (Hauner\&Peiris, 2005). According to Hauner and Peiris (2005) testing for the degree of effective competition requires a structural, contestability approach which is in line with the industrial organization literature. They indicated that the degree of competition in the banking system should be measured with respect to the actual behavior of bank conduct.

There is a vast academic literature on the measurement of competition in the banking industry. Mason (1939) and Bain (1951) developed the Structure-Conduct-Performance (SCP) paradigm. This approach resulted to three main structural hypotheses (Mkrtchyan, 2005). Bain (1951) proposed the market power hypothesis that suggested that in a highly concentrated market, firms could act collusively and thus achieve high profits.

Currently, there are two major approaches that may be used to evaluate the level of market power within a particular sector. These approaches differ according to whether the underlying model of the sector is structural or nonstructural (Bikker\&Haaf, 2001).The structural approach uses concentration ratios, such as the Herfindahl-Hirschman Index (HHI), to form hypotheses about the relationship between concentration and market structure.

There is a major debate among the structuralists about the relationship between market structure and concentration. The discourse is centered on the contestability hypothesis and the Structure-Conduct-Performance (SCP) hypothesis. The SCP hypothesis affirms that there is a nonlinear increasing relationship between market power and concentration (Cetorelli, 1999). That is, as the market becomes more concentrated, the banks tend to collude and act as a monopoly in setting prices above the competitive level. This implies that consumer welfare and concentration is inversely related. One of the advantages of using the test applied to SCP hypothesis is that the market price need not be known for the regression model to be estimated. A drawback of the SCP hypothesis is the fact that it does not permit quantification of the market power it finds. For this reason it makes sense to use other sources of information on competition as well (Bikker\& Boss, 2005).

The contestability hypothesis suggests that even in the face of increased concentration, incumbent banks may still behave competitively once there is a potential free entrant who can offer similar services at lower costs (Baumol et al., 1982). According to Baumol et al. (1982), if market entry-exit conditions were relatively free, then a monopolist would be interested in preventing entry by setting prices as if in a competitive market. Therefore, the best choice for the government is to encourage the forces of the market to operate suggested the proponents of the efficiency hypothesis. However, proponents of the contestability hypothesis prefer lowering of the entry-exit barriers. There is another argument that the positive relationship between market power and concentration may be due to the incumbent banks being forced by a hypothetical entrant to increase their market share by lowering the price of their products (to equal costs, in the case of "perfect contestability") rather than exploit their efficiency advantages.

This view implies that greater concentration may lead to a higher level of consumer welfare. As a result of the present ambiguity, efforts have been made to test the relationship empirically. However, the findings are still ambiguous. While Berger and Hannan (1989) found evidence to support the SCP paradigm, Jackson (1992) found the relationship to be nonmonotonic and even negative for high levels of concentration; this contradicts the SCP study found by Cetorelli (1999). Furthermore, other studies have been inconclusive and have also been refuted on technical grounds (Shaffer, 1993). Apart from the ambiguity surrounding the HHI theory, there are additional areas of concern. One 
important shortcoming of the HH theory is that the Index accounts for the number of banks and their market share; it does not consider the distribution of the shares and the geographical location of the banks. This makes comparisons with other countries difficult, because of the possibility of two countries having identical HHI but different market structures resulting from the distribution of market shares (Cetorelli, 1999).

Because the structuralists are not able to define the relationship between market power and concentration, the New Empirical Industrial Organization (NEIO) is looking for nonstructural models. These models, which include those of Bresnahan (1989) and Panzar and Rosse $(1982,1987)$, do not rely on clear information about market structure to determine the level of competition (Bikker\&Haaf, 2001).

The Panzar and Rosse (PR) model could be used to test the market structure of an industry for competitiveness using the "H-statistic," which is computed by aggregating the factor price elasticities approximated from a reduced-form revenue function. The reduced-form revenue equation eliminates the problems usually encountered when trying to obtain supply-side information. This is because revenues are more likely to be recorded than the cost data necessary to execute the Bresnahan (1989) approach. The Bresnahan approach relies on aggregated data that does not account for bank heterogeneity.

The Panzar and Rosse (PR) approach may be preferred based on the availability of individual bank data. Generally, the nonstructuralist models produce similar results when, which is an important advantage of the models (Nathan \&Neave, 1989; Shaffer, 1993). This is because they have clearly defined hypotheses with specific interpretations. Thus, there is little or no room for ambiguity, as is the case with the structuralists that have three potential explanations for one relationship.

A number of studies have used either the Panzar and Rosse (PR) $(1982,1987)$ or the Bresnahan (1989) methodology to the issue of competition in the financial sector, specifically for the banking system. Shaffer (1989) applied the Bresnahan methodology to a sample of U.S. banks and found results that strongly reject collusive conduct but are consistent with perfect competition. In the same model, Shaffer (1993) conducted a study on competitive conditions in Canada. He found the Canadian banking system to be more competitive over the period from 1965-1989. He found the market to be relatively concentrated. He also found that the degree of competition in Canada was generally stable following regulatory changes in 1980. Shaffer (1982) applied the Panzer and Rosse model to New York banks by using data from 1979 and found new banks to be in monopolistic competition.

A broad cross-country study using the Panzar and Rosse (PR) methodology is that of Claessens and Laeven (2004).

They use bank-level data to estimate the extent to which changes in the prices of input prices are shown in revenues generated by specific banks in 50 countries' banking systems. They then associate this competitiveness measure to indicators of countries' regulatory regimes and the structures of the banking system. They found systems with greater foreign-bank entry and fewer entry and activity restrictions to be more competitive. Important and consistent with some of the other studies, they found no evidence that their competitiveness measures negatively relate to banking system concentration or the number of banks in the market. Their findings suggest that measures of market structure do not translate in measures of effective competition, consistent with contestability determining effective competition.

The financial sector's efficiency and health are of great importance to economic growth (Boubakri, Cosset, Fischer, \&Guedhami, 2005). Competition in the financial sector plays an important role in ensuring the benefits of static and dynamic efficiency (Claessens\&Klingebiel, 2001). According to Claessens and Klingebiel (2001), the competitive banking system can improve the distribution of consumer credit, thereby enhancing the corporate sector's access to financing mitigating the risks of financial crises. Competition in the Ghanaian banking industry is increasingly important if both private and public banks are to satisfy the needs of the public at the least social cost. In well-functioning economies, banks play the role of quality controllers for successful projects looking for capital to ensure higher returns and to step up output growth. The role of the banking sector also is to ensure that credit and resources are directed to the most productive and efficient projects that contribute to future growth.

However, a competitive banking system is required to ensure that banks are effective forces for financial intermediation to channel savings into investments fostering higher economic growth (Buchs\&Mathisen, 2005). It is expected that increased competition would, in turn, foster efficiency by providing incentives to managers to cut costs in order to remain profitable. Recent research has, however, indicated that the relationship between competition and banking system performance is more complex, and that the view that competition is unambiguously good is more naïve in banking than in other industries (Claessens\&Laeven, 2004).

The degree of competition also has a profound effect on the efficiency of the production of financial services as well as the quality of financial products; and to some extent, the degree of innovation. Competition can also affect the access of 
firms and households to financial services and external financing (Claessens\&Laeven, 2004). According to Claessens and Laeven (2004), less competition in the banking system can be more costly and provide less quality services. This leads to less financing and less growth. It is, therefore, expected that increased competition in the financial sector could lead to lower costs and increased efficiency of financial intermediation, greater product innovation, and improved quality services.

According to Bikker and Boss (2005), competition in the banking market and the efficiency of banks are major factors that have an impact on both the performance and financial health of banks and on the wealth of consumers and businesses. For bank customers, competition is good because it keeps bank tariffs low and service levels high, while it also forces banks to become more efficient and stable. Studies by Beck, Demirguc-Kunt, and Levine (2003) analyzed data from a large number of countries over a period of many years and found that crises are less likely to occur in countries where there are fewer restrictions on competition and more effective arrangements to promote competition. However, a sudden increase in competition can drive individual banks closer to insolvency, thereby threatening financial stability (Bikker\& Boss, 2005).

An open and fairly regulated financial sector is more robust, more efficient and promotes the economic growth for the entire country. Another benefit of competition in an open system is that it pushes financial firms doing business in a country to give savers the highest returns and to provide investors the lowest cost of capital. Studies have shown that, under the right conditions, competition from international firms leads to narrower spreads and charges, and stimulates both savings and investment. The primary goal of the banking sector is to stimulate the economy by giving financial support to both public and private investors.

Liberalization could encourage better competition in banking markets through the removal of interest rate controls, the new entry into banking markets, and the removal of credit ceilings, thus offering banks greater liberty to compete for customers. Privatized government banks and private sector banks might be expected to compete more aggressively against each other. According to Hauner and Peiris (2005), the contribution made by a high degree of competition and efficiency can create a greater financial stability, product innovation, and access by households and firms to financial services. Yildirim and Philippatos (2007b) also show that an increase in competition can enhance the prospects for economic growth, by raising the availability of credit and financial services to businesses and households. To this effect there is a great indication that the state-dominated monopolistic, inefficient, and fragile banking systems in many low-income countries (LICs), especially in sub-Saharan Africa (SSA), are a major impediment to economic development. Despite the successful policy changes, the financial sector remains weak and can mobilize significant resources to sustain the economic program. In the spirit of this, it can be deduced that a financial reform and restructuring of the financial system is indispensable to a successful economic recovery program. For this reason it is essential to detect the kind of reforms and environments that may help to encourage competition and efficiency in the banking systems in Ghana.

Korsah, Nyarko, and Tagoe (2001) used the Herfindahl Index and Lorenz analyses to measure the intensity of bank competition in the Ghana banking sector. Their main objective was to find out whether the implementation of FINSAP had a profound effect or changes in the Ghana banking industry. Their empirical results show an increase in competition in Ghana's banking system. They further indicated that banks have become more profitable due to the oligopolistic nature of the market, which have enabled the banks to achieve abnormal profits. In the same studies, Korsah et al., used data enveloped analysis (DEA) to measure efficiency in Ghana's banking sector and found the sector to be inefficient. They attribute the inefficiency in the Ghana banking system to the overuse of capital relative to staff cost. This was due to the fact that, during the pre-FINSAP era, regulation of interest rates and the sectoral allocation of loans drove price competition from the banks. To this end, banks were compelled to respond to this situation by creating more branches to increase service levels to their customers and generate more funds. This has caused a substantial increase in capital inputs, which have contributed disproportionately to the production process. However, the inefficiency has been falling as the banks continue to react to the pressures of competition.

Barth, Caprio, and Levine (2004) draw on a large database on financial regulation and supervision to investigate the regulatory environment that sets the stage for systematic banking crises. They document that less contestable banking systems with higher entry barriers and activity restrictions exhibit higher degrees of fragility, a finding which was corroborated by Beck et al. (2003) and Beck, Demirguc-Kunt, and Levine (2006). According to Ziorklui (2001), if competition is associated by free entry and exit, it will gateway the development of new banking products, an increase in the scope of banking services and a reduction in transaction costs. One of the main objectives of the FINSAP was to enhance the soundness of the banking system through an improved regulatory and supervisory framework. In light of this, it is believed that financial reforms that are associated with the entry of new banks into the industry will provide 
competition that has led to a reduction in the dominance of the few banks which have dominated the Ghanaian banking sector. Ziorklui (2001) shows that, in the Ghanaian banking industry, entry of new banks has had little impact on the dominance of four commercial banks in Ghana. In 1990, for example, the Ghana Commercial Bank, Standard Chartered, Barclays Bank, and Social Security Bank, which held $78.95 \%$ share of total assets of the banking sector, declined slightly to $66.84 \%$ in 1997 and further declined to $51.2 \%$ in 2005 . A study by Singh (2005) suggested that bank supervisors should place more emphasis on effective corporate governance in banks. This will enable them to reduce the likelihood of unmanageable risks.

The relationship between market power and access to and costs of external financing might be influenced by the ownership structure of banks. Domestically owned banks might have extra information and superior approaches to enforcement than foreign-owned banks and so might be more willing to lend to opaque borrowers. Government-owned banks are mostly nonprofit-maximizing and often have the explicit mandate to lend to certain groups of borrowers (Beck et al., 2004). The banking system in Ghana has been characterized by government ownership which has led to the lack of competitive environment and political patronage. A government ownership of banking institutions results in more control and more interest rates regulation, which negatively affects the allocation functions of interest rates in a market economy (Ziorklui, 2001). The financial repressionist theory developed by McKinnon (1973) and Shaw (1973) considers the role of government intervention in the financial markets as the major constraint to savings mobilization, investment, and growth. In general, all of these studies find that banking market are best described as monopolistically competitive. This paper uses the Panzar and Rosse technique to examine competition in the Ghanaian banking industry.

\section{Data Consideration and Sources}

This study is conducted using average time series data and covers the period from 1985-2011. The data were obtained from the Bank of Ghana annual reports, and International Financial Statistical yearbooks. The period of 1985-2011 was chosen for two reasons. First, the early 1980s was a period in which the banking system was rendered ineffective and suffered substantial losses from a number of bad loans in their portfolios. Second, many policy changes were made in this era to strengthen the banking system through financial reforms. Shaffer (1993) used time series data for the aggregated banking sector, and estimated an average degree of competition over a long period of time in the Canadian banking industry. Gischer and Stiele (2009) also applied time series data to assess the competitive conditions in the German banking market for the period from 1993 to 2002.

\subsection{Panzar and Ross Model}

This section of the paper provides the theoretical basis of the Panzar and Rosse (PR) model (Panzar\&Rosse, 1987). In many country studies of competitiveness, two types of empirical tests of competition are typically applied. One is based on the models of Bresnahan (1989) and Lau (1982), which typically yield an estimated parameter providing a measure of the degree of imperfect competition. The empirical advantage is that it can use aggregate industry data (Claessens\&Laeven, 2004). This study adopts the other empirical approach which is based on Rosse and Panzar (1977), and Panzar and Rosse $(1982,1987)$.

As mentioned before, the Panzar and Rosse (PR) approach depends on the basis that banks will utilize different pricing strategies in reply to changes in input costs; the strategy depends on the market structure in which they operate. Therefore, whether a bank operates in a competitive market or exercises some monopoly power can be deduced from an analysis of that bank's revenue as it reacts to changing input prices (Bikker\&Haaf, 2002; Claessens\&Laeven, 2004).

This section of the study outlines the Panzar and Rosse $(1982,1987)$ model. Their model uses individual bank data to approximate a reduced-form revenue equation. The nature of competition in the banking sector is evaluated using the H-statistic which is the sum of the factor price elasticities which are also obtained from the estimation (Claessens\&Laeven, 2004; Panzer \&Rosse, 1987; Vesala, 1995). The test is derived from a general banking market model that determines the equilibrium output and the number of banks by maximizing profits at both the bank's level and the industry level.

Economic theory shows that a firm will be at profit maximization when the marginal revenue equals marginal cost (Bikker\& Boss, 2005). Following Bikker and Haaf (2002), let's consider a representative bank $i$. The twofold profit optimization condition applies at the industry and firm levels. At the former level, the zero profit constraint must hold.

$$
\mathrm{R}_{\mathrm{i}}\left(\mathrm{y}_{\mathrm{i}}^{*}, \mathrm{Z}_{\mathrm{i}}^{\mathrm{R}}\right)=\mathrm{C}_{\mathrm{i}}\left(\mathrm{y}_{\mathrm{i}}^{*}, \mathrm{~W}_{\mathrm{i}}, \mathrm{Z}_{\mathrm{i}}^{\mathrm{c}}\right) \text {. }
$$

In the above Equation $1, \mathrm{R}_{\mathrm{i}}$ refers to revenues and $\mathrm{C}_{\mathrm{i}}$ refers to the costs of bank $i, \mathrm{y}_{\mathrm{i}}$ is the output of bank $i, \mathrm{~W}_{\mathrm{i}}$ is a $\mathrm{K}$-dimensional vector of factor input prices of bank $i$; $\mathrm{Z}_{\mathrm{i}}^{\mathrm{R}}$ is a vector of $J$ exogenous variables that shift the bank's 
revenue function, and $Z_{i}^{\mathrm{c}}$ is a vector of $L$ exogenous variables that shift the bank's cost function (Bikker\&Haaf, 2002). At the individual level, marginal revenues must equal marginal costs: This is written as:

$$
\mathrm{R}_{\mathrm{i}}^{\prime}\left(\mathrm{y}_{\mathrm{i}}{ }^{*}, \mathrm{Z}_{\mathrm{i}}^{\mathrm{R}}\right)=\mathrm{C}_{\mathrm{i}}^{\prime}\left(\mathrm{y}_{\mathrm{i}}{ }^{*}, \mathrm{~W}_{\mathrm{i}}, \mathrm{Z}_{\mathrm{i}}^{\mathrm{c}}\right) \text {. }
$$

The variables that are marked with asterisks $(*)$ represent equilibrium values. The prime denotes marginal. Market power is measured by the degree to which a change in factor input prices $(\partial \mathrm{wkt})$ is reflected in the equilibrium revenues $\left(\partial \mathrm{R}_{1}{ }^{*}\right)$ earned by bank 1 (Bikker\&Haaf, 2002; Buchs\&Mathisen, 2005). Panzar and Rosse (1987) define a measure of competition, the so-called "H statistic," as the sum of the elasticities of the reduced-form revenues with respect to factor prices. This is written in equation form as:

$$
\mathrm{H}=\frac{\sum \partial \mathrm{R}_{\mathrm{t}}{ }^{*} \mathrm{w}_{\mathrm{k} \mathrm{l}}}{\partial \mathrm{w}_{\mathrm{kl}} \mathrm{R}_{\mathrm{l}}{ }^{*}}
$$

According to Panzar and Rosse (1987), the conclusion about the type of market structure is made based on the size and sign of the H-statistic. That is, both the size and sign are used to differentiate between the different market structures. The logic behind the $\mathrm{H}$-statistic rests solely on microeconomic theory, which outlines how revenues react to changes in input prices for the different market structures.

Essentially, an increase in these costs reduces revenues for a firm benefiting from monopoly power, but increases that of a firm in a market that is perfectly competitive, fairly. Therefore, it is expected that a perfectly competitive market has an $\mathrm{H}$-statistic equal to one, while the monopolist has a negative $\mathrm{H}$-statistic. The monopolistically competitive market should have an $\mathrm{H}$-statistic that is somewhere between zero and one. Positive values of $\mathrm{H}$ indicate that the data are consistent with monopolistic competition but not with individual profit maximization as under monopoly conditions.

Although banks behave like monopolists, they make no profit because other banks offer imperfect rival products due to the market entry or exit. In this case, banks produce more and the price is smaller than would be the best in each individual case (Bikker\&Haaf, 2002; Claessens\&Laeven, 2004). An increase in input prices raises both marginal and average costs without altering, under certain conditions, the optimal output of any individual firm. In reaction to the increased input prices, banks will be forced to increase prices (example interest rates on loans) until they cover the increased costs in order to survive the competition.

During this adjustment process, the inefficient banks might be acquired by efficient ones or be eventually driven out of the market by competition. The exit of some firms causes a rise in the demand faced by each of the remaining firms, leading to a prices increase and revenues equivalent to the increase in costs (Claessens\&Laeven, 2004).

Shaffer (1982) shows that the H-statistic is a unit for a natural monopoly operating in a perfectly contestable market and also for a sales-maximizing firm that is subject to breakeven constraints. Panzar and Rosse (1987) further show that not only is the sign of the H-statistic important, but so too is its size, that is, a larger H-statistic means that the market is more competitive, implying that the H-statistic is a continuous measure of competition. Claessens and Laeven (2004) argue that the $\mathrm{H}$-statistic is a more appropriate measure for the degree of competition than previously used proxies for competitive conduct.

However, Shaffer (2004) argues that the superiority and analytical strength of the H-statistic, over previously used measures of competition, is because of its formal derivation from profit-maximizing equilibrium conditions. Shaffer (2004) further argued that the statistic is only drawn from the characteristics of reduced-form revenue equations at the firm level and, therefore, not considered as robust with respect to the market.

The empirical application of the Panzar and Rosse (PR) approach usually assumes log-linearity in the specifications of the marginal revenue and cost functions. For estimation purposes, the log-specification is intended to avoid heterokedasticity.

$$
\begin{gathered}
\operatorname{Ln}\left(\mathrm{R}_{\mathrm{i}}^{\prime}\right)=\alpha_{0}+\alpha_{1} \operatorname{Ln}\left(\mathrm{y}_{\mathrm{i}}\right)+\sum_{j=1}^{J} \mathrm{~d}_{\mathrm{j}} \operatorname{Ln}\left(\mathrm{z}^{\mathrm{R}}{ }_{\mathrm{ji}}\right) . \\
\operatorname{Ln}\left(\mathrm{C}^{\prime} \mathrm{i}\right)=\mathrm{c}_{0}+\mathrm{c}_{1} \operatorname{Ln}\left(\mathrm{y}_{\mathrm{i}}\right)+\sum_{k=1} \mathrm{~b}_{\mathrm{k}} \operatorname{Ln}\left(\mathrm{w}_{\mathrm{ki}}\right)+\sum_{l=1}^{L} \mathrm{v}_{\mathrm{j}} \operatorname{Ln}\left(\mathrm{z}^{\mathrm{c}}{ }_{1 \mathrm{i}}\right) .
\end{gathered}
$$


For a profit-maximizing bank the equilibrium output results from Equation 2:

$$
\begin{aligned}
& \alpha_{0}+\alpha_{1} \operatorname{Ln}\left(\mathrm{y}_{\mathrm{i}}^{*}\right)+\Sigma \mathrm{d}_{\mathrm{j}} \operatorname{Ln}\left(\mathrm{z}_{\mathrm{ji}}^{\mathrm{R}}\right)=\mathrm{c}_{0}+\mathrm{c}_{1} \operatorname{Ln}\left(\mathrm{y}_{\mathrm{i}}^{*}\right)+\stackrel{K}{\Sigma} \mathrm{b}_{\mathrm{k}} \operatorname{Ln}\left(\mathrm{w}_{\mathrm{ki}}\right)+\stackrel{L}{\Sigma} \mathrm{v}_{\mathrm{l}} \operatorname{Ln}\left(\mathrm{z}_{\mathrm{li}}^{\mathrm{c}}\right) . \\
& j=1 \quad k=1 \quad l=1
\end{aligned}
$$

Rearranging terms:

$$
\operatorname{Ln}\left(\mathrm{y}_{\mathrm{i}}^{*}\right)=1 / \alpha_{1}-\mathrm{c}_{1}\left\{\mathrm{c}_{0}-\alpha_{0}+\sum_{k=1}^{K} \mathrm{~b}_{\mathrm{k}} \operatorname{Ln}\left(\mathrm{w}_{\mathrm{ki}}\right)+\sum_{l=1}^{L} \mathrm{v}_{\mathrm{l}} \operatorname{Ln}\left(\mathrm{z}^{\mathrm{c}}{ }_{\mathrm{li}}\right)-\sum_{j=1}^{J} \mathrm{~d}_{\mathrm{j}} \operatorname{Ln}\left(\mathrm{z}_{\mathrm{ji}}^{\mathrm{R}}\right)\right\} .
$$

The reduced-form equation for revenues of the representative bank is given by the product of the equilibrium output of bank $_{\mathrm{j}}$ and the common price level:

$$
\operatorname{Ln}\left(\mathrm{R}_{\mathrm{i}}^{*}\right)=\operatorname{Ln}\left(\mathrm{p}^{*} \mathrm{y}_{\mathrm{i}}^{*}\right) \text {. }
$$

The price level is provided by the inverse demand equation, which also reads in logarithms:

$$
\operatorname{Ln}(\mathrm{p})=\mu+\lambda \operatorname{Ln}(\mathrm{Y})
$$

where:

$$
\mathrm{Y}=\sum_{i=1}^{l} \mathrm{y}_{\mathrm{i}}
$$

is the aggregate output of the industry.

After a bit of algebra, the reduced-form revenue equation is achieved:

$$
\operatorname{Ln}\left(\mathrm{R}_{\mathrm{i}}^{*}\right)=\alpha+\sum_{\mathrm{k}=1}^{K} \beta_{\mathrm{k}} \operatorname{Ln}\left(\mathrm{w}_{\mathrm{ki}}\right)+\underset{\mathrm{q}=1}{Q} \sum_{\mathrm{q}} \operatorname{Ln}\left(\mathrm{z}_{\mathrm{q}}\right)
$$

where $Z_{\mathrm{i}}$ is a vector of $\mathrm{Q}$ bank-specific variables, without explicit reference to their origin from the cost or revenue functions, $\mathrm{Z}_{\mathrm{i}}=\left(\mathrm{z}_{\mathrm{li}} \ldots \mathrm{Z}_{\mathrm{Qi}}\right)$.

Hence, the $\mathrm{H}$-statistic is calculated as follows:

$$
\mathrm{H}=\sum_{k=l}^{K} \beta_{\mathrm{k}} .
$$

The H-statistic abridges in a single figure the overall level of competition prevailing in the market under consideration (Gutiérrez de Rozas, 2007).

An advantage of the Panzar and Rosse (PR) model is that it does not require quantity data and output price, which are not quickly available most of the time or which are costly to obtain. Because reduced-form revenue equations can be approximated without estimating the structural equations, data availability is less an issue (especially for the supply side).Furthermore, the need for correcting the quality disappears since output prices are not involved. Another advantage of the Panzar and Rosse (PR) model is that it deals with the aggregate banking activities in a country, and provides a snapshot of competitive conditions in totality (Matthews et al., 2007). Another benefit of the model is that it can incorporate bank-specific factors in the production function by using firm-level data. It also allows the user to examine the differences among banks arising from type (e.g., commercial vs. savings), size (large vs. small), ownership (domestic vs. foreign, or state vs. private), and so on (Claessens\&Laeven, 2004).

\subsubsection{Research Design}

In applying the Panzar and Rosse (PR) model, it is necessary to openly define the production activity of the banks because they are not analogous to other types of firms. The current literature offers two alternative approaches: the production approach and the intermediation approach that can be utilized in empirical work. There is some amount of debate, however, as to which approach should be taken in empirical work. This study follows the intermediation approach, which classifies deposits and loans as inputs and outputs, respectively (Huges, Mester, \& Moon, 2001). 
The intermediation method treats banks as financial intermediaries that produce output only in terms of their assets, using their labor, liabilities, and capital. Deposits are handled as inputs that are intermediated into banks' loans and investments; interest on deposits is a component of total cost, together with labor and capital costs. This also reflects the realities of the banking system in Ghana as it attempts to cross the threshold to modern banking. The production approach views banks as firms that use capital and labor to produce loans and deposits; since deposits are considered as output, the interest expense on deposits is not included in the costs (Berger, Rosen, \&Udell, 2003).

Although banks can somehow differentiate themselves through specialization in certain areas and through the provision of new services, the Panzar-Rosse method cannot describe the degree of competition in each division of banking markets separately. It is a means of approximating the overall competitive conduct in a given banking system.

Following the work of Claessens and Laeven (2004), Bikker and Haaf (2002), and Bikker and Boss (2005), this study adopts the Panzar and Rosse (PR) model with a few modifications. The model is estimated in log-linear form. The hypotheses with respect to the likelihood that competition increased with or without financial restructuring are tested using the following model in Equations 13 and 14. With these models, the H-statistic for Ghana's banking sector is estimated.

$$
\begin{aligned}
\operatorname{lnTREV}=\alpha_{0}+\alpha_{1} \ln \mathrm{PL}+ & \alpha_{2} \ln \mathrm{PK}+\alpha_{3} \ln \mathrm{PF}+\alpha_{4} \ln \mathrm{nA}+\alpha_{5} \operatorname{lnINFL}+\alpha 6 \ln \mathrm{PCGDP} \\
& +\alpha_{7} \operatorname{lnOWN}+\alpha_{8} \operatorname{lnLIB}+\varepsilon
\end{aligned}
$$

Where:

$$
\begin{aligned}
\text { TREV } & =\text { total revenue to total assets } \\
\mathrm{PL} & =\text { personnel expenses to employees (proxy for input price of labor) } \\
\mathrm{PK} & =\text { ratio of other expenses to total fixed assets (unit cost of fixed assets) } \\
\mathrm{PF} & =\text { ratio of annual interest expenses to total deposit (unit cost of funds) } \\
\mathrm{TA} & =\text { total assets (proxy for economies or diseconomies of scale) } \\
\mathrm{INFL} & =\text { inflation } \\
\mathrm{PCGDP} & =\text { per capita GDP } \\
\mathrm{OWNS} & =\text { ownership, } \\
\mathrm{LIB} & =\text { liberalization, } \\
\mathrm{Ln} & =\text { natural logarithm, } \\
\varepsilon & =\text { error term }
\end{aligned}
$$

In this study, the dependent variable is specified: and TREV as the ratio of total (gross) operating revenue to total assets in model (13). The first specification in which the dependent variable is only the interest part of total revenue is consistent with the approach that financial intermediation constitutes the core business in commercial banking. Although interest revenue still constitutes the principal source of banks' earnings, recent studies on banking activities report an increasing share of noninterest income from fee-based products and services and off balance-sheet credit substitutes in total revenues. Given the increased level of competition in financial markets, this can be explained partly by the desire of financial services firms to expand their revenue-generating sources without altering their risk and thus their capital structures, materially (Bikker\& Boss, 2005). For this reason, it is appropriate to include total revenues in the model in addition to interest revenues. Bikker and Groeneveld (2002) used the log ratio of interest revenue to total assets as the dependent variable. DeBandt and Davis (2000) used the logarithm of interest revenue for the same purpose.

The independent variables include firm-specific variables similar to those used in other studies (Al-Muharrami, Matthews, \&Khabari, 2006; Molyneux et al., 1994; Nathan \&Neave, 1989; Yildirim\&Philippatos, 2007). The model posits that banks use three input factors, namely, deposits, labor, and physical capital. The variables PF, PL, and PK are the unit prices of these inputs. PL represents the ratio of personnel expenses to total assets; PK represents the ratio of noninterest expenses to fixed assets. PF also represents the ratio of interest expenses to deposits and other liabilities. As mentioned earlier, the H-statistic measures the sum of the elasticties of banks' total revenue with respect to input prices. Hence the H-statistic for Ghana's banks is calculated as the sum of the input prices coefficients $\alpha_{1}$ to $\alpha_{3}$ as shown in Equation 14: 


$$
\mathrm{H}=\sum_{j=1}^{J} \alpha_{j}
$$

where $j=1 \ldots J$, and $J$ is the number of inputs included in the calculations and the two extreme cases of monopoly and perfect competition.DeBandt and Davis (2002) employ these variables in their model in order to assess competition and contestability in the European banking sector.

One of the variables that can be used to determine the size of a financial institution or a firm is its total assets. To this effect, the log of total assets (TA) is used as a proxy for economies or diseconomies of scale, given the wide range of bank asset sizes in Ghana's banking systems. The size variable of TA accounts for cost differences is related to banks' size and also controls for greater portfolio and loan diversification associated with larger banks. An important implication of asset diversification is less risk and, hence, a lower required rate of return. Buchs and Mathisen (2005) used size (total assets) as an explanatory variable to determine the degree of competition and bank efficiency in the Ghana banking industry. They found size to be significant and positive in all of their models. This implies that size is one of the major determinants of total revenue as well as the interest revenue.

The general economic development, macroeconomic stability, and institutional framework are controlled, since they are expected to affect the banking system performance. Demirguc-Kunt, Laeven, and Levine (2004) found that the banking system structure indicators have a weaker relationship with competitiveness indicators in more advanced countries than less developed countries. As a proxy for the general level of development of Ghana, the logarithm of per capita GDP (PCGDP) is incorporated into the model.

Buchs and Mathisen (2005) used state ownership and foreign ownership as dummy variables in their model to measure competition and bank efficiency in Ghana. They found a negative relationship between state-ownership bank and interest revenue. This captures the fact that state-owned banks have embarked on extensive lending to public enterprises which are prone to defer interest payments. With regard to foreign ownership, it was found to be positive and significant in the total revenue and interest revenue model estimation. Their results seem to confirm that foreign banks are more competent than public institutions in generating noninterest income, notably through the extensive use of commissions and fees. In this respect, a variable for public or state and private ownership is included in the model as an explanatory variable (OWNS). This variable is expected to have a positive sign.

The financial sector reforms have given the needed platform for the banking sector to operate on the basis of functional autonomy and operational flexibility, thereby improving productivity, efficiency, and profitability. Also, the reforms brought structural changes in the financial sector and succeeded in relaxing external constraints on its operation, introducing transparency in reporting procedures, restructuring and recapitalizing banks, and enhancing the competitive element in the market (Aryeetey, 2005). Liberalization could stimulate greater competition in the banking markets through several channels.

These include the new entry into the banking markets, the removal of interest rate control, and credit ceiling, which should allow banks greater freedom to compete for customers and the privatization of government banks: Private sector banks might be expected to compete more aggressively against each other than banks owned by the public sector. To this purpose, liberalization policies (LIB) are incorporated into the model as a dummy variable.LIB is specified as to examine the effect of the structural changes in the banking sector in Ghana on the competitive condition in the sector.

\section{Robustness Check}

One of the key assumptions underlying the Panzar and Rosse model is that the banks analyzed are in a state of long-run competitive equilibrium (Bikker, Spierdijk\& Finnie, 2006; Panzar\&Rosse, 1987). In such a situation, risk-adjusted rates of returns are equalized across banks, and return on assets (ROA) and returns on equity (ROE) are uncorrelated with input prices in equilibrium. An empirical test for long-run competitive equilibrium is obtained from the regression model in Equation 8, with the dependent variable replaced by ROA. This is given by Equation 15:

$$
\begin{aligned}
\ln R O A=\beta_{0}+\beta_{1} \ln P L & +\beta_{2} \ln \mathrm{IK}+\beta_{3} \ln \mathrm{PF}+\beta_{4} \operatorname{lnTA}+\beta_{5} \ln \mathrm{nNFL}+\beta_{6} \ln \mathrm{PCGDP} \\
& +\beta_{7} \operatorname{lnOWNS}+\beta_{8} \ln \mathrm{ln} \mathrm{IB}+\varepsilon
\end{aligned}
$$

In Equation 16, ROA is the dependent variable. All the explanatory variables remain the same as in Equations 13 and 14. ROA is the pre-tax return on assets (pre-tax profits to total assets), because ROA can take on (small) negative values due to bank losses in any year (Claessens\&Laeven, 2004). Following Claessens and Laeven (2004), the 
dependent variable is computed as $\mathrm{ROA}=\ln (1+\mathrm{ROA})$, where ROA is the unadjusted return on assets. Hence the equilibrium E-statistic is given as the sum of $\beta_{1}+\beta_{2}+\beta_{3}$ as shown in Equation 16:

$$
\mathrm{E}=\sum_{j=1}^{J} \beta_{j}
$$

Testing for $\mathrm{H} 0: \mathrm{H}=0$ (equilibrium) against $\mathrm{H} 1: \mathrm{H}<0$ (disequilibrium), this model provides a direct empirical way of testing for long-run equilibrium by means of a one-tailed t-test. F-test is used to test whether $\mathrm{E}=0$ or not; $\mathrm{E}$ equals to zero indicates equilibrium. If rejected, $(\mathrm{E}<0)$ the market is assumed to be in disequilibrium (Al-Muharrami, Matthews, \&Khabari, 2006; Claessens\&Laeven, 2004). The idea behind this test is that in equilibrium, returns on bank assets should not be related to input prices. This approach for testing whether the observations are in long-run equilibrium has previously been used in the literature (Bikker et al., 2006; Claessen\&Laeven, 2004). It should also be noted that equilibrium does not mean that competitive conditions are not allowed to change during the sample period. It only implies that changes in banking are taken as gradual (Al-Muharrami, Matthews, \&Khabari, 2006).

\section{Results}

Table 2 presents the results of TREV Model 1.

Table 2. Regression results of the first estimated model (TREV) for Ghana's banking system for the pre and post liberalization period (1985-1998, 1999-2011)

\begin{tabular}{lll}
\hline TREV (MODEL 1) & PRE-LIBERALIZATION & POST-LIBERALIZATION \\
\hline INTERCEPT & $1.46802^{* * *}$ & $1.46802^{* * *}$ \\
& $(4.349)$ & $(4.349)$ \\
PL & $0.04968^{*}$ & $0.39740^{* *}$ \\
& $(2.123)$ & $(3.056)$ \\
PK & $1.60852^{* * *}$ & $1.33463^{* * *}$ \\
& $(5.943)$ & $(5.272)$ \\
PF & $0.69837^{* * *}$ & $1.54327^{* * *}$ \\
& $(4.807)$ & $(6.309)$ \\
TA & $0.44978^{*}$ & $0.44978^{*}$ \\
& $(-2.398)$ & $(-2.398)$ \\
INFL & 0.08689 & 0.08689 \\
& $(1.83)$ & $(1.83)$ \\
PCGDP & 0.01007 & 0.01007 \\
& $(0.465)$ & $(0.465)$ \\
F.PRIV & $1.40145^{* *}$ & $1.40145^{* *}$ \\
& $(3.810)$ & $(3.810)$ \\
LIB & $0.20456^{*}$ & $0.20456^{*}$ \\
& $(2.403)$ & $(2.403)$ \\
R & $88.74 \%$ & \\
Pval & .001 & \\
F-test & $51.5 * * *$ & \\
\hline
\end{tabular}

Note: Values in parentheses are $\mathrm{t}$-values. $\mathrm{ROA}=$ return on asset; $\mathrm{PL}=$ personnel expenses to employees; $\mathrm{PK}=$ ratio of other expenses to total fixed assets; $\mathrm{PF}=$ ratio of annual interest expenses to total deposit; $\mathrm{TA}=$ total assets; INFL $=$ annual rate of inflation; PCGDP = per capita GDP; F.PRIV = ownership; LIB = dummy variable (liberalization). Pre = pre-liberalization; Post $=$ post-liberalization $*$ Significant at the .10 level. $* *$ Significant at the .05 level. ***Significant at the .01 level.

The estimated regression equation explains 98.63 percent in the TREV equation. The test confirms the chosen independent variables are highly explanatory. The $\mathrm{F}$ test was used to determine whether the regression equation explained a significantly greater amount of the total bank revenues than would be accounted for by random chance. The F ratio was 51.5, determined to be significant at .01 level. The t-ratios were used to determine the significance of the explanatory variables. The reported coefficient for PL was -0.04968 and is negative and significant during the preliberalization period. The negative coefficient can be associated with lack of bank professionals during the 1980s. A positive coefficient of 0.39740 was achieved and significant at the .05 level at postliberalization period. This was consistent with the results achieved by Buchs and Mathisen (2005). A positive sign for the PL during the 
postliberalization period seems more plausible. This is due to changes in the staff composition. Since the entire spectrum of employees is comprised in the computation of the labor price, rises in PL could spring from a higher proportion of highly qualified workers. The coefficient of factor price, such as the unit price of capital PK, has positive signs during both the pre- and postliberalization period and is significant at .01 level in both cases. The regression coefficient for both pre- and postliberalization was 1.60852 and 1.33463 , respectively. The positive relationship may also replicate the actuality of such costs which are more significant for merchant banks that depend more heavily on commission and fees as a source of income than for other types of banks with larger branch networks. The coefficient for PF during the pre- and postliberalization period was 0.69837 and 1.54327 , respectively. The reported coefficients were positive and were determined to be significant at the .01 level. The positive coefficient during preliberalization implies that the increased cost factor leads to higher revenue. This indicates that 1 cedi increase in annual interest expenses to total deposit will have a profound increase in total revenue. The reported coefficient for total assets (TA) at both pre- and postliberalization was -0.44978 . The coefficient is negative and statistically significant at 10 level. This suggests that size-induced differences between banks may lead to lower total revenue per unit of assets and that larger banks seem to be less efficient compared to smaller banks. This may also justify that larger banks may not be able to influence the pricing strategy of smaller banks. It seems sensible that in order to obtain a more representative and realistic picture of the actual level of competition, those banks with more assets and larger number of customers ought to have a greater impact on the banking market. Bikker and Groeneved's (2000) report consists in estimating a model where banks are weighted according to their size in terms of total assets.

The reported coefficient of inflation, INFL, was 0.08689 and is positive and significantly correlated with total revenue at the 0.01 level. This is consistent with the results obtained by Buchs and Mathisen (2005). The estimated coefficient for per capita GDP at both pre- and postliberalization was 0.35313 and is positive and significant at 0.01 level The implication is that the per capita GDP used as a measure of economic development is associated with less bank competition. This is consistent with the results achieved by Berger, Klapper, and Tur-Aris (2008). The regression coefficient for F.PRIV, the fraction of banks that are privately owned was 1.40145 and is positive and statistically significant at the .05 level in the total revenue estimation model in both the pre- and postliberalization period.

This result materializes to corroborate that foreign and domestic private banks are more effective than public institutions in generating noninterest income, notably through the extensive use of commissions and fees. The result may be explained both in terms of efficiency in generating revenue and in terms of more cautious lending policy, as reflected in lower provisioning for bad loans. The result also demonstrates the potential positive role of foreign ownership on competition in Ghana's banking sector. Empirical evidence generally is still mixed. Claessens and Laeven (2004) on one hand found a positive correlation between foreign banks' presence and competition in 53 countries. Gelos and Rolds (2002) reached the same conclusion in eight countries of Latin America and Europe. Yeyati and Micco (2003) on the other hand found that foreign-bank presence actually weakened competition in Latin America. The regression coefficient for the dummy variable (LIB) that capture the effect of financial restructuring during the pre- and postliberalization period was 0.20456 and was determined to be positive and significant at 0.10 level.

\subsection{Determination of H-Statistics}

Based on bank-level information on 25 banks, H-statistics were calculated for Ghana's banking system using the Panzar-Rosse model. Banks without adequate data were dropped from the analysis. This is to aid the regression and produce precise $\mathrm{H}$-statistic for the determination of the degree of competition. The following variables, unit price of labor, unit cost of fixed assets, unit cost of funds, total assets, per capita gross domestic product, inflation rate, fraction of banks that are privately owned and liberalization variable. These bank-level data were used to calculate the H-statistics and were obtained from various issues of the Bank of Ghana annual reports between 1988 and 2008. The $\mathrm{H}$-statistics which serve as a measure of the degree of competition is based on the factor price elasticities presented by the Panzar and Rosse (PR) (1987) model. If the H-statistic is less than or equal to zero, the market is classified as a monopoly or collusion. If the $\mathrm{H}$-statistic on the other hand is more than zero and less than one, the market is classified as monopolistic competition. When the H-statistic is one, the market is perfectly competitive. If the H-statistic is greater than one, then the standard cost conditions would propose that revenue is augmented by more than costs when factor prices rise. To determine whether the restructuring policies have had some impact on the degree of competition, economic indexes such as inflation and per capita GDP were incorporated into the model as a control variable and the liberalization variable. To calculate the $\mathrm{H}$-statistic, the regression models developed in section 5 indicated by equations 13 is used:

The regression Model 1 uses the sum of the elasticities of three factor inputs: unit price of labor, unit cost of fixed asset, and unit cost of fund. This is consistent with other competition studies (Bikker\&Haaf, 2002; Buchs\&Mathisen, 2005; 
Claessens\&Laeven, 2004). The factor input prices are followed by other bank-specific factors that reflect differences in costs, total assets (TA), and the fraction of banks that could influence the cost and revenue functions underlying the Panzar and Rosse model. These other bank-specific factors are held constant in computing the factor input elasticities by including them in the multiple regression equation. Other economic variables such as inflation (INFL), per capita GDP (PCGDP) used as control variables are held as constant in computing the factor input elasticities. LIB is a dummy variable for liberalization.

As stated in section 5, the $\mathrm{H}$-statistic is defined as the sum of elasticities of the regression model variables with respect to factor input prices: the sum of the coefficients $\beta_{1}, \beta_{2}$, and $\beta_{3}$ of the first 3 regression variables.

Table 3 summarized the H-statistics in model 1 for 25 banks in Ghana during pre- and postliberalization periods.

Table 3.

TREV Summary of H-Statistic

\begin{tabular}{llll}
\hline & H-statistic & SE & P-val \\
\hline Pre-Liberalization & 2.35657 & 0.02628 & 0.001 \\
Post-Liberalization & 3.27530 & 0.08719 & 0.005 \\
Change in H-statistic & 0.91873 & 0.62214 & 0.87 \\
\hline
\end{tabular}

Author's calculation

For the sample of 25 banks in Ghana, the change in average H-statistics is 0.91873 For both the preliberalization and postliberalization periods, the statistical test indicated a significant departure from monopoly $(p<0.001$ and $p=0.005$ for pre- and postliberalization, respectively). Since the H-statistic is more than one, perfect competition can be used to describe the Ghana's banking market. The test for a change in competition status at the time of liberalization was not significant $(\mathrm{p}=0.87)$, indicating no evidence of a change in competition as a result of liberalization.

Based on the results of the $\mathrm{H}$-statistic reported in Tables 3 for model 1, it can be deduced that the Ghanaian banks are operating under perfect competition. Under perfect competition, the H-statistic equals unity. In this particular situation, a proportional increase in factor input prices induces an equally proportional change in revenues without distorting the optimal output of any individual firm. Contestable markets would also generate an $\mathrm{H}$-statistic equal to unity. The contestability theory, first stated by Baumol, Panzar, and Willig (1982), enables the existence of competition in highly concentrated scenarios under very restrictive circumstances. Basically, free entry and exit of market participants, neither economic nor legal entry barriers completely costless exit, and highly price elastic demands for industry's output on account of these features, the threat of potential new market participant's forces larger firms to price their output in a competitive manner. The result achieved by this study is not consistent with the result obtained by Buchs and Mathisen (2005) who found Ghana's banks to be operated under monopolistic competition between 1998 and 2003. Overall, the Panzar and Rosse model is regarded as a valuable tool for assessing the banking market conditions in Ghana since a bank's revenue is more likely to be observable than output prices and quantities or actual costs, data availability becomes less of a constraint and helps to explain why this model has been most successfully applied than the Iwata or the Bresnahan-Lau models.

\subsubsection{Market Equilibrium or Robustness Check}

As noted in section 5, the Panzar-Rosse model assumes that banks operate in their long-run equilibrium stages, thus implying that their returns should not be statistically correlated with the current input prices. To this effect, if the ROA of the banks statistically correlate with input prices, then the market is not considered to be in equilibrium. In this stance, the Panzar and Rosse (PR) model cannot be applied (Molyneuz et al., 1994). For the long-run equilibrium test, the researchers follow the existing literature by running the original regression model in equation 11 with return on assets being the new dependent variable. As suggested by Molyneux and colleagues (1994), under this specification, a value of $\mathrm{H}=0$ would indicate an equilibrium in the banking market under investigation.

In order to generate the market equilibrium statistic or standard error for Ghana's banking system; banks without adequate data were dropped from the analysis. The study maintains the same variables that appear in the equation 16 in section V. Performance of the long-run equilibrium test for individual years and sample periods for the data were conducted. First, the study runs the regression model with return on asset (ROA) as the dependent variable, to determine whether the market is in the long-run equilibrium.

As indicated in equation 16 in section $\mathrm{V}$, the $\ln (1+\mathrm{ROA})$ is the natural $\log$ of 1 plus return on assets for bank $\mathrm{i}_{\mathrm{i}}$, based on individual bank data for the period 1988-2011, in time t. The value of the dependent variable (1+ROA) is used since 
ROA can be negative for certain banks on occasion. The regression model uses three factor inputs: unit price of labor (PL), unit cost of fixed asset (PK), and unit cost of funds (PF) for the market equilibrium, which was built on the Panzar and Rosse model.

The factor input prices are followed by other bank-specific factors when calculating the market equilibrium statistic. These other bank-specific factors such as total assets, inflation, per capita GDP, fraction of banks that are privately owned and the dummy variable (LIB) could influence the cost and revenue functions underlying the Panzar and Rosse model. The $\mathrm{F}$ test is used to test the market equilibrium hypothesis, i.e., $\mathrm{H}=0$ hypothesis. Ordinary least-square (OLS) were used to estimate the model. The estimates are equivalent to maximum likelihood estimates assuming that random errors come from a normal distribution. The $\mathrm{F}$-statistic for testing hypothesis $\mathrm{H}=0$ indicates that the null hypothesis can only be rejected for the years under study at any conventional significance levels.

The result of the ROA Model 2 is presented in Table 4.

Table 4. Regression results of the first estimated model (ROA) for Ghana's banking system for the pre and post liberalization period (1985-1998, 1999-2011)

\begin{tabular}{lll}
\hline ROA (MODEL 2) & PRE-LIBERALIZATION & POST-LIBERALIZATION \\
\hline INTERCEPT & $0.54388^{* * *}$ & $0.54388^{* * *}$ \\
PL & $0.06633^{*}$ & 0.05464 \\
& $(2.434)$ & $(1.273)$ \\
PK & $0.110886^{* *}$ & $0.07577^{*}$ \\
& $(2.783)$ & $(1.792)$ \\
PF & $0.110886^{* *}$ & $0.183364^{* * *}$ \\
& $(3.058)$ & $(7.377)$ \\
TA & 0.5699 & 0.5699 \\
& $(0.838)$ & $(0.838)$ \\
INFL & 0.01354 & 0.01354 \\
& $(1.04)$ & $(1.04)$ \\
PCGDP & $0.51899^{*}$ & $0.51899^{*}$ \\
& $(1.851)$ & $(1.851)$ \\
F.PRIV & 0.02641 & 0.02641 \\
& $(0.221)$ & $(0.221)$ \\
LIB & $0.204562^{*}$ & $0.20456^{*}$ \\
& $(2.403)$ & $(2.403)$ \\
$R^{2}$ & .8388 & \\
P-val & .001 & \\
F-test & $34.06^{* *}$ & \\
\hline Note: Values & & \\
\hline
\end{tabular}

Note: Values in parentheses are t-values. ROA = return on asset; $\mathrm{PL}=$ personnel expenses to employees; $\mathrm{PK}=$ ratio of other expenses to total fixed assets; $\mathrm{PF}=$ ratio of annual interest expenses to total deposit; $\mathrm{TA}=$ total assets; INFL $=$ annual rate of inflation; PCGDP = per capita GDP; F.PRIV = ownership; LIB = dummy variable (liberalization). Pre = pre-liberalization; Post $=$ post-liberalization $*$ Significant at the .10 level. **Significant at the .05 level. ***Significant at the .01 level.

The $\mathrm{R}^{2}$ for this model is 83.88 percent of the variability in the ROA equation. This measures the explanatory power of the independent variables. F test was used to determine whether the regression equation explained a significantly greater amount of the return on assets than would be accounted for by random chance. The F ratio of 34.06 was obtained to be significant at the .05 level. The t-ratio was used to determine the significance of the explanatory variables. The regression coefficient for PL was 0.06633 and is positive and significant during the pre-liberalization period.

The reported coefficient during the postliberalization of 0.05464 is positive and was not significant at the .10 level. This may signify some changes in the labor composition which may infuse qualified personnel in the industry. The regression coefficients for PK at both pre- and postliberalization were positive 0.110886 and 0.07577 , respectively. These were significant in both periods. The regression coefficients for PF during pre- and post-liberalization were 0.118901 and 0.183364 , respectively, and were significant. The estimated coefficients for total asset (TA) and inflation (INFL) in both pre- and post-liberalization were 0.05699 and 0.01354 , respectively. These were positive and not significant. These indicate that total assets and inflation do not have considerable patterns in the degree of competition. This is not consistent with the results obtained by other studies such as Claessens and Laeven (2004), Bikker and 
Groeneveld (2000), and Buchs and Mathisen (2005). The regression coefficient for per capita GDP (PCGDP) at preand post-liberalization period was 0.51899 and significant. This also suggests some general patterns in the degree of competition in the Ghana banking system. The regression coefficient for the fraction of banks that are privately owned was 0.02641 and is positive and not significant.The estimated coefficient for the dummy variable (LIB) was 0.204562 and was determined to be significant and positive in the ROA model. The sign agreed with the direction hypothesized. This is consistent with the results obtained by Hauner and Peiris(2005). It can be deduced that the effects of entry restrictions and subsequent opening up to new domestic and foreign participants, which are borne out by the rapid rise in the number of banks, is not associated with the liberalization policies.

Based on the regression model in equation 15, the E-statistic before liberalization is $E_{\text {pre }}=\beta_{1}+\beta_{2}+\beta_{3}$, the E- statistic after liberalization is E-post $=\beta_{1}+\beta_{2}+\beta_{3}+\beta_{4}+\beta_{5}+\beta_{6}$, and the change in the E-statistic at the point of liberalization is $\delta \mathrm{E}=\beta_{4}+\beta_{5}+\beta_{6}$

As stated in section $\mathrm{V}$, the market equilibrium statistic is defined as the sum of elasticities of the regression model with respect to factor input prices; that is, the sum of the coefficients $\beta_{1}, \beta_{2}$, and $\beta_{3}$ of the first three regression model variables $\ln \mathrm{PK}$, $\ln \mathrm{PF}$, and $\ln \mathrm{PL}$. Table 5 presents the results of the $\mathrm{H}$-statistics at equilibrium.

Table 5.

ROA Summary of H-Statistic at Equilibrium

\begin{tabular}{llll}
\hline & H-statistic & SE & P-val \\
\hline Preliberalization & 0.29612 & 0.0018 & 0.248 \\
Postliberalization & 0.31377 & 0.01026 & 0.250 \\
Change in $\delta$ E-statistic & -0.01765 & 0.00845 & 0.072 \\
\hline
\end{tabular}

Author's calculations

The results of the market equilibrium show that the market equilibrium equals to zero. This reveals the existence of long-run equilibrium and the $\mathrm{F}$ test doesnot reject the null hypothesis $\mathrm{H}=0$ leading us to conclude that the banking industry was in the long-run at equilibrium over the period 1985-2011. That is, the null hypothesis $\mathrm{H}=0$ cannot be rejected at the 5 percent level; the data appear to be in a long-run equilibrium, thus allowing Panzar and Rosse's statistic to be meaningfully interpreted. For both the preliberalization and postliberalization periods, the statistical test did not indicate that the E-statistic was significantly different from zero. We conclude that there is no statistical evidence that the market was out of equilibrium either before or after liberalization. Not surprisingly, the test for a significant change in equilibrium at the point of liberalization was also not significant. This conclusion is consistent with other studies that have made contributions in applying Panzar and Rosse's model statistic (Bikker and Haaf, 2002; De Bandt and Davis, 2000). With respect to the equilibrium test, it should be noticed that — as argued by De Bandt and Davis (1999, p.10) - equilibrium does not mean that competitive conditions are not allowed to change, an assumption which would be contradicted by the period that we consider, characterized by a process of structural changes. It only implies that changes in banking are taken as gradual. This occurred in the Ghanaian banking system throughout the 1990s. It was characterized by regulations and deregulations which relax a lot of restrictions. For example the entry and exit movements of banks appear to be gradual.

\section{Conclusion}

The Ghanaian banking system has undergone a number of major changes caused by the restructuring of the banking industry. This study examines the competitive conditions in the Ghana banking industry, while explicitly controlling for the bank specific factors such as risk, total assets, inflation, and per capita GDP for the period 1985-2011. For a transition country like Ghana, this period corresponds to an era characterized by substantial reforms to restructure the banking system, and to liberalize and deregulate sufficiently their financial systems in order to integrate economically with the advanced Western world. The basis of measuring the degree of competition was the application of the model developed by Panzar and Rosse (1987).

By applying the Panzar-Rosse methodology for the period 1985-2011, we find that the Ghanaian banking market is consistent with perfect competition, with the values of the H-statistic lying between one and above. The results of the competition analysis suggest that the banking markets of Ghana cannot be characterized by the bipolar cases of either monopolistic competition or monopoly over the period of study. That is, banks earned their revenue as if operating under conditions of perfect competition in that period. It is believed that the larger banks relatively operate more in a competitive environment than the smaller banks. The results show an increasing trend in competition after 1997 revealing the inevitable impact of liberalization on competitive conditions. As an overall conclusion, for Ghana's banking system, banking marketing structure can be characterized as perfect competition. However, the results of this study are different from the study undertaken by Buchs and Mathisen (2005), who found Ghanaian banking markets to operate under monopolistic conditions. Two reasons can be explained to this issue. First, Buchs and Mathisen 
concentrated on five years long samples. Such coverage may turn out to be insufficient to separate the fundamentals underlying banks' behavior. Secondly they accounted only the larger commercial banks data for their studies. Since commercial data sources are sometimes biased in favor of larger firms, the actual level of competition might be underestimated.

This study has extended and strengthened some earlier results on bank competition in Ghana. Three remarkable innovations of the current study are the use of a comprehensive data source, the consideration of a longer period of time covering two decades (1988-2011), and the incorporation of the liberalization factor. Obviously, the purpose is to provide a reliable background for an accurate implementation of the Panzar and Rosse approach in determining the degree of competition in the Ghana's banking market.

The conclusion of this study shows a variety of specifications controlling for bank size, risk, and various deposit composition characteristics, and a number of estimation techniques. Our findings are consistent with the results obtained by Yuan (2006) and Gutiérrez de Rozas (2007) and who found Chinese and Spanish banking market respectively to be near perfect competition

\section{References}

Al-Muharrami, S. (2009). Analysis of competitiveness in Qatar banking industry. International Journal of Business Innovation and Research, 3(2), 168-181. http://dx.doi.org/10.1504/IJBIR.2009.022753

Al-Muharrami, S., Matthews, K., \& Khabari, Y. (2006). Market structure and competitive conditions in the Arab GCC banking system. Journal of Banking \& Finance, 30, 3487-3501. http://dx.doi.org/10.1016/j.jbankfin.2006.01.006

Aryeetey, E., \& Kanbur, R. (2005). Ghana's economy at half century: An overview of stability, Growth and poverty. Institute of Statistical, Social \& Economic Research. University of Ghana, Legon.

Aryeetey, E., \& Senbet, L. W. (2004). Essential financial market reforms in Africa. Institute of Statistical, Social \& Economic Research.University of Ghana, Legon.

Bain, J. S. (1951). Relation of profit rate to industry concentration. Quarterly Journal of_Economics, 65, 293-324. http://dx.doi.org/10.2307/1882217

Bank of Ghana. (2007, May). Financial stability report. 7(2). Ghana.

Bank of Ghana Annual Reports, 2005.

Barth, J. R., Caprio, G. Jr., \& Levine, R. (2004). Bank supervision and regulation: What works best? Journal of Financial Intermediation, Forthcoming. http://dx.doi.org/10.1016/j.jfi.2003.06.002

Baumol, W. J. (1982). Contestable markets: An uprising in the theory of industry structure. American Economic Review, 72, 1-15.

Baumol, W., Panzar, J., \& Willig, R. (1982). Contestable markets and the theory of industry structure. New York: Harcourt Brace Jovanovich.

Beck, T. (2008). Bank Competition and financial stability: Friends or foes? Policy research Working Paper. WPS4656. The World Bank. Development Research Group.

Beck, T., Cull, R., \& Jerome, A. (2005). Bank privatization and performance: Empirical Evidence from Nigeria. Journal of Banking \& Finance, 29, 2355-2379. http://dx.doi.org/10.1016/j.jbankfin.2005.03.018

Beck, T., Demirgüç-Kunt, A., \& Laeven, L. (2007). Finance, inequality and the poor. Journal of Economic Growth, 12, 27-49. http://dx.doi.org/10.1007/s10887-007-9010-6

Beck, T., Demirguc-Kunt, A., \& Levine, R. (2003). Bank concentration and crises. NBER Working Paper Series no. 9921, National Bureau of Economic Research, Cambridge, Massachusetts. Retrieved from http://www.nber.org/papers/w9921

Beck, T., Demirguc-Kunt, A., \& Levine, R. (2006). Bank concentration, competition, and crises: First results. Journal of Banking \& Finance, 30, 1581-1603. http://dx.doi.org/10.1016/j.jbankfin.2005.05.010

Beck, T., Demirguc-Kunt, A., \& Maksimovic, V. (2004). Bank competition and access to Finance International evidence. Journal of Money, Credit and Banking, 36(3), 627-648. http://dx.doi.org/10.1353/mcb.2004.0039

Berger, A. N., Demirguc-Kunt, A., Levine, R., \& Haubrich, J. G. (2004, June). Bank concentration and competition: An evolution in the making. Journal of Money, credit and Banking, 36(3), 433-451. http://dx.doi.org/10.1353/mcb.2004.0040

Berger, A. N., Hasan, I., \& Klapper, L. F. (2004). Further evidence on the link between finance and growth: An international analysis of community banking and economic performance. Journal of Financial Services Research, 25, 169-202. http://dx.doi.org/10.1023/B:FINA.0000020659.33510.b7 
Berger, A. N., Klapper, L. F., \& Turk-Ariss. (2008). Bank competition and financial stability. Policy Research Working Paper 4696. The World Bank.

Berger, A. N., Saunders, A., Scalise, J. M., \& Udell, G. F. (2000). The Globalization of Financial Institutions: Evidence from cross-border banking performance. Brookings-Wharton Papers on financial services, 3, 23-158. http://dx.doi.org/10.1353/pfs.2000.0001

Berger, A., \& Hannan, T. (1989). The price concentration relationship in banking. The Review of Economics and Statistics, 71, 291-229. http://dx.doi.org/10.2307/1926975

Bikker, J. A., \& Boss, J. W. B. (2005, Autumn). Competition and efficiency in banking: international comparisons. Economic \& Financial Modelling, 103-139.

Bikker, J. A., \& Groeneveld. (2000). Competition and concentration in the EU banking industry. Kredit und Kapital, $33,62-98$.

Bikker, J. A., \& Haaf, K. (2002). Competition, concentration and their relationship: An empirical Analysis of the banking industry. Journal of Banking and Finance, 26, 2191-2214. http://dx.doi.org/10.1016/S0378-4266(02)00205-4

Bikker, J., \& Boss, J. (2004). Trends in competition and profitability in the banking industry: A basic Framework De Nederlandsche Bank NV. Working Paper No. 018/2004. The Netherlands.

Bikker, J., \& Haaf, K. (2001). Competition, concentration, and their relationship: an empirical analysis of the banking industry. Working Paper De Nederlandsche Bank.

Bikker, J., Spierdijk, L., \& Finnie, P. (2006). Misspecification of the PanzarRosse model: Assessing competition in the banking industry. DNB Working Paper No. 114.

Bonin, J. P., Hasan, I., \& Wachtel, P. (2005a). Bank performance, efficiency and ownership in Transition countries. Journal of Banking and Finance, 29, 31-53. http://dx.doi.org/10.1016/j.jbankfin.2004.06.015

Bonin, J. P., Hasan, I., \& Wachtel, P. (2005b). Privatization matters: Bank performance in transition countries. Journal of Banking and Finance, 29.

Boubakri, N., Cosset, J., Fischer, K., \& Guedhami, O. (2005). Privatization and bank performance in developing countries. Journal of Banking \& Finance, 29, 2015-2041. http://dx.doi.org/10.1016/j.jbankfin.2005.03.003

Bresnahan, T. F. (1989). Empirical studies of industries with market power. In Schmalensee, R., \& Willig, R.D. (Eds), Handbook of Industrial Organisation II (pp. 1012-1055). http://dx.doi.org/10.1016/S1573-448X(89)02005-4

Buchs, T., \& Mathisen, J. (2005). Competition and efficiency in banking behavioral evidence from Ghana. IMF Working Paper WP/05/07. International Monetary Fund.

Cetorelli, N. (1999). Competitive analysis in the banking: appraisal of the methodologies economic perspectives. Federal Reserve Bank of Chicago.

Cetorelli, N., \& Strahan, P. (2006). Finance as a barrier to entry: Bank competition and industry structure in local U.S. markets. The Journal of Finance, LXI(1), 437-461. http://dx.doi.org/10.1111/j.1540-6261.2006.00841.x

Claessens, S., Demirguc-Kunt, A., \& Huizinga, H. (2001). How does foreign entry affect banking markets? Journal of Banking and Finance, (25), 891-911. http://dx.doi.org/10.1016/S0378-4266(00)00102-3

Claessens, S., \& Klingebiel, D. (2001, Spring). Competition and scope of activities in financial services. The World Bank Research Observer, 16(1), 19-40. http://dx.doi.org/10.1093/wbro/16.1.19

Claessens, S., \& Laeven, R. (2003). Financial development, property rights and growth. Journal of Finance, 58(6), 2401-2436. http://dx.doi.org/10.1046/j.1540-6261.2003.00610.x

Claessens, S., \& Laeven, L. (2003). Competition in the financial sector and growth: A cross-Country perspective. Working Paper.

Claessens, S., \&Laevan, R. (2004). What drives bank competition? Some International Evidence. Journal of Money, Credit and Banking, 36(2), 563-584. http://dx.doi.org/10.1353/mcb.2004.0044

Claessens, S. (2009). Competition in the financial sector: Overview of competition policies. The World Bank Research Observer, 24(1), 83-118. http://dx.doi.org/10.1093/wbro/lkp004

Cetorelli, N. (2004, June). Real effects of bank competition. Journal of Money, Credit and Banking, 36(3), 545-558.

DeBandt, O., \& Davis, P. E. (1999). A cross-country comparison of market structures in European banking. ECB Working Paper 7. 
DeBandt, O., \& Davis, P. E. (2000). Competition, contestability and market structure in European banking sectors on the eve of the EMU. Journal of Banking and Finance, 24, 1045-1066. http://dx.doi.org/10.1016/S0378-4266(99)00117-X

Dell'Aricca, G., Igan, D., \& Laeven, L. (2008). Creidit booms and lending standards: Evidence from the subprime mortgage market. IMF Working Papers, 45(1), 81-109.

Demirguc-Kunt, A., \& Detragiache, E. (1999). Financial liberalization and financial fragility. In B. Pleskovic \& J. E. Stiglitz (Eds.), Proceedings of the 1998 World.

Demirguc-Kunt, A., Laeven, L., \& Levine, R. (2004). Regulations, market structure, institutions and the cost of financial intermediation. Journal of Money, Credit and Banking, 36, 593-622. http://dx.doi.org/10.1353/mcb.2004.0045

Gelos, G., \& Roldos, J. (2002). Consolidation and market structure in emerging market banking systems. IMF Working Paper 02/186. Washington, DC: International Monetary Fund.

Gelos, G., \& Roldos, J. (2004). Consolidation and market structure in emerging market banking systems. Emerging Market review, 5, 39-59. http://dx.doi.org/10.1016/j.ememar.2003.12.002

Gischer, H., \& Stiele, M. (2009). Competition tests with a non-structural model: the Panzar-Rosse method applied to Germany's Savings Banks. German Economic Review, 10(1), 50-70. http://dx.doi.org/10.1111/j.1468-0475.2008.00441.x

Gutiérrez de Rozas, L. (2007). Testing for competition in the Spanish banking industry: The Panzar-Rosse approach revisited. Documentos de Trabajo No. 0726 Banco de España Eurosistema. Retrieved from http://www.bde.es

Haber, S., \& Perotti, E. (2008). The political economy of finance. Journal of Economic Literature, 21(3), 114-132.

Hauner, D., \& Peiris, S. J. (2005). Bank efficiency and competition in low-income countries: The case of Uganda. IMF Working Paper No. 05/240. Washington: International Monetary Fund.

Hellmann, T. F., Murdock, K., \& Stiglitz, J. (2000). Liberalization, moral hazard in banking prudential regulation: are capital requirements enough? American Economic Review, 90, 147-165. http://dx.doi.org/10.1257/aer.90.1.147

Huges, J., Mester, L., \& Moon. (2001). Are scale economies in banking elusive or illusive? evidence obtained by incorporating capital structure and risk-taking into models of bank production. Journal of Banking and Finance, 25, 2169-2208.

International Monetary Fund (IMF). (1996). International Financial Statistics Yearbook.

International Monetary Fund (IMF). (2007). International Financial Statistics Yearbook.

Jackson, W. (1992). The Price-concentration relationship in banking: A comment. Review of Economics and Statistic, 74, 373-376. http://dx.doi.org/10.2307/2109676

Korsah, K., Nyarko, E. K., \&Tagoe, N. A. (2001). Impact of financial sector liberalization on competition and efficiency in the Ghanaian banking industry. International Labor Organization Research paper, 01-2, 1-51.

Lau, L. (1982). On identify the degree of competitiveness from industry price and outputdata. Economics Letters, 10, 93-99. http://dx.doi.org/10.1016/0165-1765(82)90122-7

Levine, R. (2003). Denying foreign bank entry: Implications for bank interest margins. Mimeo University of Minnesota.

Levy Yeyati, E., \& Micco, A. (2007). Concentration and foreign bank penetration in Latin American banking sectors: Impact on competition and risk. Journal of Banking and Finance, 31, 1633-47. http://dx.doi.org/10.1016/j.jbankfin.2006.11.003

Maddala, G. S. (1988). Introduction to econometrics. New York: Macmillian Publications.

Mason, E. S. (1939). Price and Production Policies of large-scale enterprise. American Economic Review, 29, 61-74.

Matthews, K., Murinde, V., \& Zhao, T. (2007). Competitive conditions among the major British banks. Journal of Banking \& Finance, 31, 2025-2042. http://dx.doi.org/10.1016/j.jbankfin.2006.11.009

McKinnon, R. I. (1973). Money and capital in economic development. The Brookings Institution. Washington, DC.

Micco, A., Panizza, U., \& Yanez, M. (2007). Bank ownership and performance. Does politics Matter? Journal of Banking \& Finance, 31, 219-241. http://dx.doi.org/10.1016/j.jbankfin.2006.02.007

Mkrtchyan, A. (2005). The evolution of competition in banking in a transition economy: An application of the Panzar-Rosse model to Armenia. The European Journal of Comparative Economics, 2(1), 67-82. 
Molyneux, P., \& Nguyen-Linh, H. (2008). Competition and risk in the South East Asian banking. Bangor Business School Working Paper, Bangor Wales.

Molyneux, P., Lloyd-Williams, D. M., \& Thornton, J. (1994). Competitive conditions in European banking. Journal of Banking and Finance, 18, 445-459. http://dx.doi.org/10.1016/0378-4266(94)90003-5

Nathan, A., \& Neave, E. (1989). Competition and Contestability in Canada's Financial System: Empirical Results. The Canadian Journal of Economics, 22, 576-594. http://dx.doi.org/10.2307/135541

Otchere, I. (2005). Do privatized banks in middle-and low-income countries perform better Than rival banks? An intra analysis of bank privatization. Journal of Banking \& Finance, 29, 2067-2093. http://dx.doi.org/10.1016/j.jbankfin.2005.03.001

Panzar, J. C., \& Rosse, J. N. (1982). Structure, conduct and comparative statistics. Bell Laboratories Economics, Discussion Paper No. 248.

Panzar, J. C., \& Rosse, J. N. (1987). Testing for monopoly equilibrium. Journal of Industrial Economics, 35, 443-456. http://dx.doi.org/10.2307/2098582

Perotti, E. C., \& Suarez, J. (2002). Last bank standing: What do I gain if you fail? European Economic Review, 46(9), 1599-622. http://dx.doi.org/10.1016/S0014-2921(02)00241-6

Rosse, J. N., \& Panzar, J. C. (1977). Chamberlin v.s Robinson: an empirical study of monopoly rents. Bell Laboratories Economic Discussion Paper.

Shaffer, S. (1982). A non-structural test for competition in financial market. In bank structure and competition. Conference Proceedings, Federal Reserve bank of Chicago, 225-43.

Shaffer, S. (1989). Competition in the U.S. banking industry. Economics Letters, 29(32), 1-23.

Shaffer, S. (1993). A test of competition in Canadian banking. Journal of Money, Credit and Banking, 25, 49-61. http://dx.doi.org/10.2307/2077819

Shaffer, S. (1994). Bank competition in concentrated markets. Business Review, 3(4), 3-17.

Shaffer, S. (2004). Comment on what drives bank competition? Some international evidence by Claessens, S. and Laeven, L. Journal of Money, Credit and Banking, 36(3), 585-92. http://dx.doi.org/10.1353/mcb.2004.0050

Shaw, E. S. (1973). Financial deepening in economic development. New York:Oxford University Press.

Singh, D. (2005). Basel committee on banking supervision compliance and the compliance Function in banks. Journal of Banking Regulation, 6(4), 298-300. http://dx.doi.org/10.1057/palgrave.jbr.2340198

Stigler, G.J. (1964). A theory of oligopoly. Journal of Political Economy, 72, 44-61. http://dx.doi.org/10.1086/258853

Vesala, J. (1995). Testing competition in banking: behavioral evidence from Finland. Bank of Finland Studies, E: 1, Helsinki.

World Bank. (1986). Financial sector review. World Bank. Washington, DC.

World Bank. (1994). Ghana financial sector review: Bringing savers and investors together. World Bank Report No. 13423-GH. Washington, DC.

Yeyati, E. L., \& Micco, A. (2007). Concentration and foreign penetration in Latin American Banking sectors: Impact on competition and risk. Journal of Banking \& Finance, 31, 1633-1647. http://dx.doi.org/10.1016/j.jbankfin.2006.11.003

Yildirim, H. S., \& Philippatos, G. C. (2006). Bank efficiency: Evidence from the transition Economies of Europe. European Journal of Finance, Forthcoming.

Yildirim, H. S., \& Philippatos, G. C. (2007a). Competition and contestability in central and Eastern European banking markets. Managerial Finance, 33(3), 195-209. http://dx.doi.org/10.1108/03074350710718275

Yildirim, H. S., \& Philippatos, G. C. (2007b). Restructuring, consolidation and competition in Latin American banking markets. Journal of Banking \& Finance, 31, 629-639. http://dx.doi.org/10.1016/j.jbankfin.2006.06.008

Yuan, Y. (2006). The state of competition of the Chinese banking industry. Journal of Asian Economics, 17(3), 519-534. http://dx.doi.org/10.1016/j.asieco.2006.05.001

Ziorklui, S. Q. (2001). The Impact of Financial sector reforms on bank efficiency and financial Deepening for savings mobilization in Ghana. African Economic Policy Discussion Paper 81. Retrieved from www.eagerproject.com/discussion81.shtml 